\title{
Effect of indoor air pollution on infant and child-mortality in Myanmar: Evidence from the first Demographic and Health Survey
}

\author{
Juwel Rana ${ }^{1,2}$, Md Nuruzzaman Khan $^{3}$, Razia Aliani ${ }^{4}$ and Rakibul M Islam ${ }^{5}$
}

${ }^{1}$ Department of Biostatistics and Epidemiology, University of Massachusetts Amherst, MA01003, United States of America

${ }^{2}$ South Asia Institute for Social Transformation (SAIST), Dhaka 1205, Bangladesh

${ }^{3}$ School of Medicine and Public Health, Faculty of Health and Medicine, University of Newcastle, Australia, and Lecturer, Department of Population Sciences, Jatiya Kabi Kazi Nazrul Islam University, Mymensingh, Bangladesh

${ }^{4}$ Methods Team, Cochrane France

${ }^{5}$ Department of Epidemiology and Preventive Medicine, School of Public Health and Preventive Medicine, Monash University (Australia), Melbourne VIC 3004, Australia 
medRxiv preprint doi: https://doi.org/10.1101/19010801; this version posted November 2, 2019. The copyright holder for this preprint (which was not certified by peer review) is the author/funder, who has granted medRxiv a license to display the preprint in perpetuity.

It is made available under a CC-BY-NC-ND 4.0 International license.

\section{Abstract}

\section{Background}

Indoor air pollution (IAP) from solid fuels for cooking has been considered as a public health threat, particularly for women and children in low- and lower-middle-income countries (LMICs). We investigated the effects of solid fuel use (SFU) on neonatal, infant and underfive child mortality in Myanmar.

\section{Materials and Methods}

We used data from Myanmar’s first Demographic and Health Survey conducted in 2016. The sample consists of ever-married mothers with under-five children in the household $(n=3249)$. We calculated the adjusted odds ratio (aOR) to investigate the effects of SFU on neonatal, infant, and under-five mortality using multivariable logistic regression model accounting for survey weight and clustering. Additional analysis was conducted using an augmented measure of the exposure to IAP accounting for both SFU and the location of cooking (high exposure, moderate, and unexposed).

\section{Results}

The prevalence of SFU was $79.0 \%$, and the neonatal, infant and the under-five mortality rates were 26, 45 and 49 per 1,000 live births, respectively. The odds of infant (aOR 2.17, 95\% CI: 1.21, 3.88) and under-five child mortality (aOR 2.22, 95\% CI: 1.24, 3.95) were higher in households with SFU compared with households with clean fuel use. When applying an augmented measure of exposure to IAP by incorporating both SFU and the kitchen's location, the likelihood of infant and under-five mortality was higher among moderately and highly 
medRxiv preprint doi: https://doi.org/10.1101/19010801; this version posted November 2, 2019. The copyright holder for this preprint (which was not certified by peer review) is the author/funder, who has granted medRxiv a license to display the preprint in perpetuity. It is made available under a CC-BY-NC-ND 4.0 International license.

exposed children compared to unexposed children with similar trends. Neonatal mortality was not associated with both SFU and levels of exposure to IAP.

\section{Conclusion}

Infants and under-five children are at higher risk of mortality from exposure to IAP. The findings suggest that the risk of infants and under-five child mortality may be reduced by increasing access to clean cookstoves and clean fuels in LMICs, especially in Myanmar.

Keywords: Air pollution, Solid fuel, Child, Mortality, Myanmar 
medRxiv preprint doi: https://doi.org/10.1101/19010801; this version posted November 2, 2019. The copyright holder for this preprint (which was not certified by peer review) is the author/funder, who has granted medRxiv a license to display the preprint in perpetuity. It is made available under a CC-BY-NC-ND 4.0 International license .

\section{Background}

Indoor air pollution (IAP) is one of the world's major environmental threats, causing about 4 million premature deaths annually (1). IAP related mortality is disproportionately higher in low and middle-income countries (LMICs). In 2017, almost $70 \%$ of all deaths related to IAP occurred in LMICs (2). About 3 billion people use solid fuels for cooking, including coal and biomass (wood, animal dung, lignite, charcoal, wood, straw/shrubs, grass, and agricultural crop) $(3,4)$, which are the major sources of IAP (1).

In contrast, alternative fuel (clean fuel) such as liquefied petroleum gas and electricity is often unavailable and/or unaffordable in LMIC (5). Therefore, households opt to collect solid fuels (3), which are burned indoors in conventional cookstoves as a pit, pieces of brick, or U-shaped mud construction. These solid fuels emit damaging airborne pollutants, including PM10, NOx, $\mathrm{CO}$, SOx, formaldehyde and many toxic polycyclic aromatic hydrocarbons and other organic matter due to inefficient combustion (6-8). The amount of exposure to an individual in such settings has been measured to be much higher than the World Health Organization (WHO) guidelines and standards (9).

In LMICs, women and children are at higher risk of exposure to SFU $(10,11)$ due to women's role in household chores, cooking, and caring for infants in most South Asian culture. Women spend about three to seven hours per day near the stove, sometimes carrying their infants for care and warmth during cooking that leads children exposed to biomass fuel at similar levels (3). This exposure level increases in households with limited ventilation and poor design of the stove that do not have flues or hood to move out the smoke from living places (12). 
medRxiv preprint doi: https://doi.org/10.1101/19010801; this version posted November 2, 2019. The copyright holder for this preprint (which was not certified by peer review) is the author/funder, who has granted medRxiv a license to display the preprint in perpetuity. It is made available under a CC-BY-NC-ND 4.0 International license .

The majority of the population in Myanmar use solid fuels for cooking as easy access to biomass for domestic cooking is a convention (13). Clean Cooking Alliance, Myanmar estimated that more than $95 \%$ of the rural and $88 \%$ of the urban population use solid fuels for cooking, which might be one of the causes of more than 3,500 yearly infant and children death from ALRIs and pneumonia in Myanmar $(13,14)$. It could also be one of the reasons that Myanmar could not achieve the Millennium Development Goals (between 2000 and 2015) targets of reducing infant and child mortality (15). Importantly, this indicates an important area to address for achieving the Sustainable Development Goals of reducing neonatal (12 per 10000 live birth) and infant (25 per 10000 live births) deaths between 2015 and 2030 .

No study, to our knowledge, has evaluated the effect of IAP from SFU on infant and underfive mortality rates using nationally representative data of Myanmar. The first Demographic Health Survey (DHS) in Myanmar was conducted in 2016 that provides an opportunity for us to examine the effect of SFU in the household on neonatal, infant and under-five mortality, comparing the magnitude of the effect based on the exposure levels.

\section{Materials and Methods}

\subsection{Study design}

Given the focus on improving maternal and child health, Myanmar Demographic and Health Survey (MDHS) 2016 was the first nationally representative survey conducted in Myanmar in 2015-16. Data were collected from 12,885 women from the sampled households based on stratified two-stage cluster sampling design. Using the 2014 Myanmar census sampling units, 442 clusters (123 urban, 319 rural) were selected in the first stage from 4,000 clusters through the probability proportional to the unit sizes. In the second stage, 30 households from each 
medRxiv preprint doi: https://doi.org/10.1101/19010801; this version posted November 2, 2019. The copyright holder for this preprint (which was not certified by peer review) is the author/funder, who has granted medRxiv a license to display the preprint in perpetuity. It is made available under a CC-BY-NC-ND 4.0 International license.

selected cluster were selected in the first stage by using systematic random sampling. The United States Agency for International Development (USAID) funded the DHS program, and the Ministry of Health and Sports, Myanmar, implemented MDHS 2016. Three Millennium Development Goals (a national level organization supported by the seven bilateral donors; Australia, Denmark, the European Union, Sweden, Switzerland, the United Kingdom and the United States of America). Technical support was provided by the ICF international. Detail of the survey sampling procedure has been published in the MDHS report (16).

\subsection{Data Source}

From 12,885 surveyed women, a sub-sample of 3,249 women were included in the analysis. The inclusion criteria were: i) women had at least one child born within five years before the date of survey; ii) respond to the question on survival status (alive/death at the time of survey) of this child; iii) respond to the question about the date of child death if applicable; and iii) respond to the question on household cooking fuels use.

\subsection{Measures of Outcomes}

We considered neonatal mortality (deaths occurred during the first 28 days of life), infant mortality (deaths occurred during the first one year (0-11 months) of life), and under-five mortality (deaths occurred during the first five years (0-59 months) of life) as outcome variables.

\subsection{Measures of Exposure to IAP}

The analysis was carried out for two exposure variables: Solid Fuel Use (type of clean fuel vs. solid fuel), and level of exposure to SFU induced IAP (unexposed, moderate exposure, and 
medRxiv preprint doi: https://doi.org/10.1101/19010801; this version posted November 2, 2019. The copyright holder for this preprint (which was not certified by peer review) is the author/funder, who has granted medRxiv a license to display the preprint in perpetuity. It is made available under a CC-BY-NC-ND 4.0 International license .

high exposure). The MDHS collected information on the type of cooking fuel by asking women, what type of fuel does your household mainly use for cooking? Responses were recoded as clean fuel $=0$ (if responses were electricity, liquid petroleum gas, and natural gas) and solid fuel =1 (if responses were coal, lignite, charcoal, wood, straw/shrubs, grass, and agricultural crop). Children's levels of exposure to IAP was generated from the women's responses to the place of cooking and the type of cooking fuel use. The responses were categorized as unexposed $=0$ (if women reported not using solid fuel), moderate exposure $=1$ (if women reported using solid fuel, but in a separate building or outdoors), and high exposure $=2$ (if women reported using solid fuel inside the house).

\subsection{Confounder adjustment}

Different sociodemographic factors that contribute to the neonatal, infant, and under-five mortality were also included as confounders. These were age at child deaths, child sex, women's education, interval of last two succeeding births, household wealth quintiles, urbanity, geographic regions, and seasons. The birth interval variable was generated based on women's response on the date of births of the last two-child and categorized by following the World Health Organization guidelines (16). The wealth quintile was generated from the women's household durable and non-durable assets (e.g., televisions, bicycles, sources of drinking water, sanitation facilities and construction materials of houses) using principal components analysis.

\subsection{Statistical analysis}

Descriptive statistics were used to characterize the demographic profile of the respondents of the study. Differences in occurring neonatal, infant and under-five deaths across 
medRxiv preprint doi: https://doi.org/10.1101/19010801; this version posted November 2, 2019. The copyright holder for this preprint (which was not certified by peer review) is the author/funder, who has granted medRxiv a license to display the preprint in perpetuity.

It is made available under a CC-BY-NC-ND 4.0 International license .

sociodemographic factors were also presented. The associations between exposure to IAP and child mortality outcomes were investigated using both univariable and multivariable logistic regression models. The univariable models included only the exposure variable and the outcome variable. These associations were then adjusted for potential confounders in the multivariable model. For each model, we used appropriate survey weights to adjust stratification and cluster variations in the survey data. Results are reported as odds ratios (OR) with $95 \%$ confidence interval $(95 \% \mathrm{CI})$. All statistical tests were two-sided, and a $p$-value $<0.05$ was considered statistically significant. All analyses were carried out using statistical software packages Stata version 15.1 (Stata Corp: College Station, TX, USA).

\section{Results}

\subsection{Sample characteristics}

Characteristics of sample, exposures, and outcomes are presented in Table 1. The mean (SD) age of the mothers was $31( \pm 6.0)$ years. The mean years of education was $4.43( \pm 3.5)$ years ( $\mathrm{SD} \pm 3.5)$. The mean age of the child was $2.11( \pm 0.04)$ months, and nearly $48 \%$ of the child was female. More than three-quarter (77.8\%) of the study households used solid fuel for cooking, of which $61.5 \%$ used solid fuel inside the house. About two-thirds (64.5\%) of the women's reported indoor place of cooking. Nearly half of the children and women (47.7\%) were highly exposed to indoor air pollution during the survey (Table 1). 
medRxiv preprint doi: https://doi.org/10.1101/19010801; this version posted November 2, 2019. The copyright holder for this preprint (which was not certified by peer review) is the author/funder, who has granted medRxiv a license to display the preprint in perpetuity.

It is made available under a CC-BY-NC-ND 4.0 International license .

Table 1: Key information about the study participants, exposure and outcome variables

\begin{tabular}{|l|l|}
\hline Demographics of mothers & Mean (SD) \\
\hline Mean age $( \pm$ SD) & $31.09( \pm 6.0)$ \\
\hline Mean weight $( \pm$ SD) & $53.90( \pm 10.9)$ \\
\hline Mean year of education $( \pm$ SD) & $4.43( \pm 3.5)$ \\
\hline Demographics of children & Mean (SD) \\
\hline Mean age in months $( \pm$ SD) & $2.11( \pm 0.04)$ \\
\hline Female & $47.6(45.4-49.8)$ \\
\hline Exposure to IAP & \% (95\% CI) \\
\hline Solid fuel use & $77.8(74.1-81.1)$ \\
\hline Solid fuel use (indoor only) & $61.5(57.7-65.2)$ \\
\hline Indoor cooking place (without SFU) & $64.5(61.0-67.8)$ \\
\hline Level of exposure to IAP & \% (95\% CI) \\
\hline Unexposed & $22.4(19.1-26.1)$ \\
\hline Moderate exposure & $29.9(26.8-33.0)$ \\
\hline High exposure & $47.7(43.9-51.6)$ \\
\hline Outcomes & $\mathbf{( 9 5 \% ~ C I ) ~}$ \\
\hline Neonatal mortality per 1000 live birth & $26(19-35)$ \\
\hline Infant mortality per 1000 live birth & $45(35-57)$ \\
\hline Under-five mortality per 1000 live birth & $49(38-62)$ \\
\hline
\end{tabular}

$\mathrm{SD}=$ standard deviation, $\mathrm{CI}=$ confidence interval, $\mathrm{IAP}=$ indoor air pollution

The rate of neonatal mortality was 26 (95\% CI: 19-53), infant mortality was 45 (95\% CI: 3557), and under-five mortality was 49 (95\% CI: 38-62) per 1000 live births (Table 1). Infant and under-five child mortality were higher among children whose mother had no education, resided in Shan, Chin, and Teninthayi regions, and were born in short birth interval (Table 2). 
Table 2: Child Mortality Outcomes by socio-demographic and spatial factors

\begin{tabular}{|c|c|c|c|}
\hline $\begin{array}{l}\text { Socio-demographic and } \\
\text { spatial factors }\end{array}$ & $\begin{array}{l}\text { Neonatal } \\
\text { mortality }\end{array}$ & Infant Mortality & $\begin{array}{l}\text { Under-five } \\
\text { mortality }\end{array}$ \\
\hline Age of the child, Mean $( \pm$ SD $)$ & $0( \pm 0.24)$ & $1.74( \pm 0.26)$ & $3.93( \pm 0.65)$ \\
\hline $\begin{array}{l}\text { Sex of child } \\
\%(95 \% \mathrm{CI})\end{array}$ & $\begin{array}{l}\text { Neonatal } \\
\text { mortality }\end{array}$ & Infant Mortality & $\begin{array}{l}\text { Under-five } \\
\text { mortality }\end{array}$ \\
\hline Male & $2.7(1.9-3.9)$ & $4.4(3.26 .0)$ & $4.8(3.5-6.5)$ \\
\hline Female & $2.5(1.6-4.0)$ & $4.6(3.3-6.3)$ & $4.9(3.6-6.7)$ \\
\hline $\begin{array}{l}\text { Mothers' age at childbirth } \\
\text { (Mean } \pm \text { SD) }\end{array}$ & $31.8( \pm 0.66)$ & $31.48( \pm 0.53)$ & $31.78(0.51)$ \\
\hline $\begin{array}{l}\text { Mothers' education } \\
\%(95 \% \text { CI) }\end{array}$ & $\begin{array}{l}\text { Neonatal } \\
\text { mortality }\end{array}$ & Infant Mortality & $\begin{array}{l}\text { Under-five } \\
\text { mortality }\end{array}$ \\
\hline None & $4.4(2.8-6.8)$ & $7.7(5.2-11.2)$ & $8.3(5.5-12.4)$ \\
\hline Primary & $1.8(1.1-3.1)$ & $3.6(2.5-5.2)$ & $4.0(2.9-5.6)$ \\
\hline Secondary & $2.1(1.2-3.7)$ & $2.9(1.8-4.8)$ & $3.0(1.9-4.9)$ \\
\hline Higher & $5.1(1.5-16.1)$ & $5.1(1.5-16.1)$ & $5.1(1.5-16.1)$ \\
\hline $\begin{array}{l}\text { Wealth quintile } \\
\%(95 \% \text { CI) }\end{array}$ & $\begin{array}{l}\text { Neonatal } \\
\text { mortality }\end{array}$ & Infant Mortality & $\begin{array}{l}\text { Under-five } \\
\text { mortality }\end{array}$ \\
\hline Poorest & $1.9(0.8-3.9)$ & $4.0(2.4-6.6)$ & $4.2(2.6-6.8)$ \\
\hline Poor & $2.1(1.1-4.1)$ & $3.2(1.9-5.5)$ & $3.8(2.2-6.6)$ \\
\hline Middle & $3.2(1.8-5.6)$ & $4.8(3.1-7.3)$ & $5.4(3.6-8.0)$ \\
\hline Richer & $2.7(1.6-4.8)$ & $5.5(3.5-8.5)$ & $5.9(3.9-9.0)$ \\
\hline Richest & $2.8(1.5-4.9)$ & $4.5(2.9-7.1)$ & $4.5(2.9-7.1)$ \\
\hline $\begin{array}{l}\text { Urbanity } \\
\%(95 \% \text { CI })\end{array}$ & $\begin{array}{l}\text { Neonatal } \\
\text { mortality }\end{array}$ & Infant Mortality & $\begin{array}{l}\text { Under-five } \\
\text { mortality }\end{array}$ \\
\hline Urban & $2.8(1.6-4.8)$ & $4.3(2.7-6.8)$ & $4.6(2.9-7.1)$ \\
\hline Rural & $2.6(1.8-3.6)$ & $4.6(3.4-6.1)$ & $5.0(3.7-6.6)$ \\
\hline $\begin{array}{l}\text { Geographic region } \\
\%(95 \% \text { CI })\end{array}$ & $\begin{array}{l}\text { Neonatal } \\
\text { mortality }\end{array}$ & Infant Mortality & $\begin{array}{l}\text { Under-five } \\
\text { mortality }\end{array}$ \\
\hline Kachin & $2.4(1.0-5.7)$ & $3.1(1.4-7.0)$ & $3.5(1.6-7.5)$ \\
\hline Kayah & $2.2(1.1-4.5)$ & $2.9(1.5-5.6)$ & $2.9(1.5-5.7)$ \\
\hline Kayin & $1.9(0.5-7.1)$ & $3.1(1.2-7.6)$ & $3.5(1.4-8.6)$ \\
\hline Chin & $5.3(3.6-7.9)$ & $7.5(5.3-10.6)$ & $8.3(5.5-12.2)$ \\
\hline Sagaing & $2.4(0.8-6.9)$ & $2.8(1.1-7.2)$ & $3.2(1.3-7.6)$ \\
\hline Tenintha & $1.7(0.6-5.0)$ & $5.2(2.0-12.7)$ & $6.9(3.2-14.3)$ \\
\hline Bago & $2.1(0.8-5.7)$ & $3.3(1.5-6.9)$ & $3.3(1.5-6.9)$ \\
\hline
\end{tabular}


medRxiv preprint doi: https://doi.org/10.1101/19010801; this version posted November 2, 2019. The copyright holder for this preprint (which was not certified by peer review) is the author/funder, who has granted medRxiv a license to display the preprint in perpetuity.

It is made available under a CC-BY-NC-ND 4.0 International license .

\begin{tabular}{|l|l|l|l|}
\hline Magway & $2.4(1.0-5.9)$ & $3.7(1.9-6.7)$ & $4.3(2.2-8.4)$ \\
\hline Mandalay & $1.3(0.3-5.0)$ & $3.8(1.6-8.6)$ & $3.8(1.6-8.6)$ \\
\hline Mon & $1.8(0.7-4.5)$ & $3.7(1.6-8.1)$ & $4.3(1.8-10.1)$ \\
\hline Rakhine & $3.3(1.4-7.6)$ & $3.8(1.8-7.6)$ & $3.8(1.8-7.6)$ \\
\hline Yangon & $2.7(0.6-11.9)$ & $4.3(1.4-12.2)$ & $4.3(1.4-12.2)$ \\
\hline Shan & $3.8(2.0-7.0)$ & $7.9(4.5-13.5)$ & $8.4(4.5-15.1)$ \\
\hline Ayeyarwa & $3.2(1.3-7.3)$ & $5.5(2.8-10.3)$ & $6.0(3.2-10.8)$ \\
\hline Naypyiataw & $0.7(0.09-4.0)$ & $2.0(0.6-5.6)$ & $2.0(0.7-5.7)$ \\
\hline $\begin{array}{l}\text { Birth interval } \\
\text { \% (95\% CI) }\end{array}$ & $\begin{array}{l}\text { Neonatal } \\
\text { mortality }\end{array}$ & Infant Mortality & $\begin{array}{l}\text { Under-five } \\
\text { mortality }\end{array}$ \\
\hline$\geq 24$ months & $2.31(1.6-3.3)$ & $3.9(3.0-5.0)$ & $4.3(3.3-5.5)$ \\
\hline$<24$ months & $4.7(2.5-8.4)$ & $8.3(5.1-13.1)$ & $8.8(5.5-13.6)$ \\
\hline $\begin{array}{l}\text { Seasons } \\
\text { \% (95\% CI) }\end{array}$ & $\begin{array}{l}\text { Neonatal } \\
\text { mortality }\end{array}$ & Infant Mortality & $\begin{array}{l}\text { Under-five } \\
\text { mortality }\end{array}$ \\
\hline Hot session & $1.5(0.8-2.8)$ & $4.6(2.8-7.5)$ & $5.1(3.0-8.7)$ \\
\hline Rainy session & $1.0(0.3-4.0)$ & $1.8(0.07-4.06)$ & $2.0(0.83-4.7)$ \\
\hline Cool session & $3.3(2.3-4.6)$ & $4.8(3.6-6.4)$ & $5.1(3.9-6.7)$ \\
\hline
\end{tabular}

\subsection{Effect of exposure to IAP on neonatal, infant and under-five child mortality}

The unadjusted and adjusted association between exposure and outcome variables are presented in Table 3. We found 2.22\% (95\% CI: 1.24-3.95) higher likelihood of under-five mortality, and $2.17 \%$ (aOR 95\% CI: 1.21-3.88) higher likelihood of infant mortality for the child of the women used solid fuel for cooking than women did not use solid fuel. The likelihoods were even higher when we considered the augmented measure of exposure to IAP. We found that the odds of occurring under-five mortality around 2.20 (95\% CI: 1.19-4.06) and 2.25 (95\% CI: 1.21-4.19) times higher among moderately and highly exposed children compared to unexposed. A similar higher likelihood of infant mortality was also observed among children with moderate (aOR 2.16 95\% CI: 1.17-4.00) and high (aOR 2.19, 95\% CI: 
medRxiv preprint doi: https://doi.org/10.1101/19010801; this version posted November 2, 2019. The copyright holder for this preprint (which was not certified by peer review) is the author/funder, who has granted medRxiv a license to display the preprint in perpetuity.

It is made available under a CC-BY-NC-ND 4.0 International license .

1.17-4.10) exposure IAP than their counterparts. There was no association between neonatal mortality with SFU and levels of exposure to IAP.

Table 3: Association between exposure to IAP and risk of neonatal, infant and under-

five mortality in Myanmar

\begin{tabular}{|c|c|c|c|c|c|c|}
\hline \multirow{3}{*}{ Exposures } & \multicolumn{6}{|c|}{ Mortality Outcomes } \\
\hline & \multicolumn{2}{|c|}{ Neonatal Mortality } & \multicolumn{2}{|c|}{ Infant Mortality } & \multicolumn{2}{|c|}{ Under-five Mortality } \\
\hline & $\begin{array}{l}\text { OR } \\
(95 \% \text { CI })\end{array}$ & $\begin{array}{l}\text { aOR } \\
(95 \% \mathrm{CI})^{++}\end{array}$ & $\begin{array}{l}\text { OR } \\
(95 \% \text { CI })\end{array}$ & $\begin{array}{l}\text { aOR } \\
(95 \% \mathrm{CI})^{++}\end{array}$ & $\begin{array}{l}\text { OR } \\
(95 \% \mathrm{C}))\end{array}$ & $\begin{array}{l}\text { aOR } \\
(95 \% \mathrm{CI})^{++}\end{array}$ \\
\hline \multicolumn{7}{|c|}{ Exposure to exposure } \\
\hline Clean fuel & 1.00 & 1.00 & 1.00 & 1.00 & 1.00 & 1.00 \\
\hline SFU & $\begin{array}{l}1.55 \\
(0.82-2.94)\end{array}$ & $\begin{array}{l}1.80 \\
(0.77-4.21)\end{array}$ & $\begin{array}{l}1.68 \\
(1.02-2.78)^{*}\end{array}$ & $\begin{array}{l}2.17 \\
(1.21-3.88)^{* *}\end{array}$ & $\begin{array}{l}1.85 \\
(1.12-3.05) *\end{array}$ & $\begin{array}{l}2.22 \\
(1.24-3.95)^{* *}\end{array}$ \\
\hline \multicolumn{7}{|c|}{ Levels of exposure to IAP } \\
\hline Unexposed & 1.00 & 1.00 & 1.00 & 1.00 & 1.00 & 1.00 \\
\hline Moderate & $\begin{array}{l}1.77 \\
(0.88-3.58)\end{array}$ & $\begin{array}{l}1.98 \\
(0.80-4.85)\end{array}$ & $\begin{array}{l}1.86 \\
(1.07-3.23)^{*}\end{array}$ & $\begin{array}{l}2.16 \\
(1.17-4.00)^{*}\end{array}$ & $\begin{array}{l}2.06 \\
(1.19-3.56)^{* *}\end{array}$ & $\begin{array}{l}2.20 \\
(1.19-4.06)^{* *}\end{array}$ \\
\hline High & $\begin{array}{l}1.42 \\
(0.72-2.79)\end{array}$ & $\begin{array}{l}1.57 \\
(0.62-3.93)\end{array}$ & $\begin{array}{l}1.59 \\
(0.94-2.70)\end{array}$ & $\begin{array}{l}2.19 \\
(1.17-4.10)^{*}\end{array}$ & $\begin{array}{l}1.74 \\
(1.03-2.95)^{* *}\end{array}$ & $\begin{array}{l}2.25 \\
(1.21-4.19)^{* *}\end{array}$ \\
\hline
\end{tabular}

${ }^{*} \mathrm{p}<0.05,{ }^{* *} \mathrm{p}<0.01$, aOR=adjusted odds ratios, $\mathrm{CI}=$ confidence interval; ${ }^{++}$Multivariable logistic models were adjusted for child age, gender, mothers' education, wealth quintiles, urbanity, geographic region, preceding birth interval and session.

\section{Discussion}

The risk factors of under-five child mortality, especially in the context of Myanmar, are underinvestigated despite their high child mortality rate. Additionally, no study, to our knowledge, has examined the effect of IAP on child mortality in Myanmar. To address this gap, this study examined the associations of SFU and exposure to IAP with neonatal, infant, and under-five child mortality using first-ever nationally representative demographic and health survey data collected in 2016. 
medRxiv preprint doi: https://doi.org/10.1101/19010801; this version posted November 2, 2019. The copyright holder for this preprint (which was not certified by peer review) is the author/funder, who has granted medRxiv a license to display the preprint in perpetuity. It is made available under a CC-BY-NC-ND 4.0 International license .

Our study suggests that the under-five mortality rate was high (48 deaths per 1,000 live births) in Myanmar. The majority of the households were dependent on SFU for cooking and heating purposes, and almost half of the study children were highly exposed to IAP in Myanmar. The study demonstrates that SFU and both moderate and high levels of exposure to IAP increased the risk of infant and under-five child mortality in Myanmar.

Previous studies reported comparable results that SFU and exposure to IAP increase the risk of infant and child mortality in LMICs (17-22). Evidence suggests that the combustion of SFU emits multiple pollutants such as fine particles, carbon monoxide, formaldehyde, and many more toxic chemicals, which increase the risk of mortality from ALRIs, asthma, and pneumonia among infant and young children exposed to these pollutants (3,6,7,23-29). Exposure to these toxic pollutants also increases the risk of low birth weight, stillbirth, and preterm birth, including acute and chronic health problems, all of which are considered as leading causes of child mortality $(20,22,30,31)$.

Previous studies emphasized to consider cooking place along with SFU for examining the association between IAP and child-mortality because cooking inside the house with solid fuels maximizes the concentrations of airborne toxic pollutants in the household and ambient air $(20,23,32,33)$. Following the previous study, we employed an inclusive SFU exposure measure combining both SFU and cooking place and found stronger associations of high exposure to IAP with infant and child mortality (23). Consistent with our study, previous studies showed that children were exposed to higher concentration of pollutants from SFU because of high proximity to pollutants and spending much time in the kitchen during heating and cooking, which intensifies the risk of child mortality from ALRI including other adverse health outcomes $(17,23,24)$. The plausible explanation is that infants at their early age are often carried 
medRxiv preprint doi: https://doi.org/10.1101/19010801; this version posted November 2, 2019. The copyright holder for this preprint (which was not certified by peer review) is the author/funder, who has granted medRxiv a license to display the preprint in perpetuity. It is made available under a CC-BY-NC-ND 4.0 International license.

on their mother's back or placed to sleep or stand beside their mother when they are cooking because this is common practice in South-East Asian countries, including Myanmar $(20,21,32,34)$.

Furthermore, young children are more susceptible to IAP induced mortality compared to the older child for their underdeveloped epithelial linings of the lungs $(23,35)$. However, women might be careful of IAP induced health effects on neonates. In a healthy condition, infants and young children have higher respiration, and they breathe 50\% more polluted air due to their narrower airway and large lung surface. Also, children have a weak immune system in their early years of life which makes them vulnerable to IAP induced mortality, especially from ALRI (35-38).

However, neonatal mortality was not significantly associated with SFU and exposure to IAP, and these results are consistent with previous research conducted in LMICs $(17,39)$. Several biological factors, such as low birth weight, prematurity, and complications associated with pregnancy and delivery, might be responsible for the null association between IAP and neonatal mortality $(20,30,40)$. Additionally, breastfeeding could work as a protective factor diminishing the effect of IAP on neonatal mortality. Moreover, neonates and mothers might live in a conducive environment right after delivery, as well as mothers, usually stay away from any cooking activities during the neonatal period, which is also a cultural practice in Asia. However, few studies claim that neonates are at higher risk of IAP induced mortality and those were inconsistent across studies $(22,41)$. 
medRxiv preprint doi: https://doi.org/10.1101/19010801; this version posted November 2, 2019. The copyright holder for this preprint (which was not certified by peer review) is the author/funder, who has granted medRxiv a license to display the preprint in perpetuity.

It is made available under a CC-BY-NC-ND 4.0 International license.

\section{Strength and weakness}

The main strength of the study was based on the first-ever conducted a nationally representative survey with $98 \%$ response rate. Moreover, the analysis of large-scale data with appropriate statistical adjustments for confounders makes this study findings more reliable for policymaking. The temporal association between IAP exposure and child mortality outcomes cannot be established due to the cross-sectional nature of the study. Besides, the associations could be affected by unmeasured confounders as well as different health outcomes such as preterm birth, low birth weight, and other morbidity factors could be associated with underfive child mortality despite the exposure to IAP. Third, information related to birth and death of the children was reported by mothers that may introduce recall bias, but it is unlikely that the mother would incorrectly report the birth and death of their children. Fourth, there might be a source of exposure measurement error as we used two proxy measures such as SFU and combining SFU and cooking place to measure the associations between IAP exposures (23) and under-five child mortality. However, this is the available robust and established measurement of exposures for IAP because DHS does not objectively measure the level and duration of IAP exposures (23,32). Further studies may include questions related to ventilation in the kitchen, duration of cooking, proximity to the kitchen, or heating areas for the better measurement of children's exposure to IAP.

\section{Conclusion}

The study demonstrates that SFU is a significant risk factor for infant and under-five child mortality but not for neonatal mortality. Furthermore, both moderate and high levels of exposure to IAP, such as the combination of SFU and cooking inside the kitchen, increase the 
medRxiv preprint doi: https://doi.org/10.1101/19010801; this version posted November 2, 2019. The copyright holder for this preprint (which was not certified by peer review) is the author/funder, who has granted medRxiv a license to display the preprint in perpetuity. It is made available under a CC-BY-NC-ND 4.0 International license .

risk of child mortality in Myanmar with a stronger effect among the children who had a high level of exposure to IAP. Policymakers should take both short-term and long-term strategies through socio-environmental pathways for addressing the problem of high child mortality rate in Myanmar. The government could decrease child mortality in Myanmar by implementing national policies related to clean fuels, cookstoves and green energy as well as reducing the level of exposures to IAP, which will ultimately help them to meet several sustainable development goals.

Acknowledgments: The authors thank to MEASURE DHS for granting access to the first-ever conducted Myanmar Demographic and Health Survey (MDHS) 2016 data.

Authors' Contribution: JR and MNK developed the study concepts. JR and MNK analyzed the data. JR, MNK, and RA wrote the original draft of the manuscript. RI supervised and edited the manuscript. All authors critically read, reviewed and approved the final version.

Funding: This research received no external funding.

Conflicts of Interest: The authors declare no conflict of interest. 
medRxiv preprint doi: https://doi.org/10.1101/19010801; this version posted November 2, 2019. The copyright holder for this preprint (which was not certified by peer review) is the author/funder, who has granted medRxiv a license to display the preprint in perpetuity.

It is made available under a CC-BY-NC-ND 4.0 International license .

\section{References}

1. World Health Organization. Household air pollution and health: Fact sheet [Internet]. 2018 [cited 2019 Apr 10]. Available from: https://www.who.int/news-room/factsheets/detail/household-air-pollution-and-health

2. Roser M, Ritchie H. Indoor Air Pollution [Internet]. Our World in Data. 2019 [cited 2019 Apr 10]. Available from: https://ourworldindata.org/indoor-air-pollution

3. Po JYT, FitzGerald JM, Carlsten C. Respiratory disease associated with solid biomass fuel exposure in rural women and children: systematic review and meta-analysis. Thorax [Internet]. 2011 Mar 1 [cited 2019 Aug 6];66(3):232-9. Available from: http://www.ncbi.nlm.nih.gov/pubmed/21248322

4. Smith KR, Mehta S. Indoor air pollution from household use of solid fuels. In: Ezzati MLA, Rodgers A MC, editor. Comparative Quantification of Health Risks: Global and Regional Burden of Disease Due to Selected Major Risk Factors Global and Regional Burden of Disease Attributable to Selected Major Risk Factors. Geneva: World Health Organization; 2004. p. 1435-93.

5. Torres-Duque C, Maldonado D, Perez-Padilla R, Ezzati M, Viegi G, Forum of International Respiratory Studies (FIRS) Task Force on Health Effects of Biomass Exposure. Biomass Fuels and Respiratory Diseases: A Review of the Evidence. Proc Am Thorac Soc. 2008 Jul;5(5):577-90.

6. Lai AM, Carter E, Shan M, Ni K, Clark S, Ezzati M, et al. Chemical composition and source apportionment of ambient, household, and personal exposures to PM2.5 in communities using biomass stoves in rural China. Sci Total Environ [Internet]. 2019 Jan [cited 2019 Aug 6];646:309-19. Available from: 
medRxiv preprint doi: https://doi.org/10.1101/19010801; this version posted November 2, 2019. The copyright holder for this preprint (which was not certified by peer review) is the author/funder, who has granted medRxiv a license to display the preprint in perpetuity.

It is made available under a CC-BY-NC-ND 4.0 International license.

https://linkinghub.elsevier.com/retrieve/pii/S0048969718328183

7. Kodros JK, Carter E, Brauer M, Volckens J, Bilsback KR, L’Orange C, et al.

Quantifying the Contribution to Uncertainty in Mortality Attributed to Household, Ambient, and Joint Exposure to PM 2.5 From Residential Solid Fuel Use. GeoHealth [Internet]. 2018 Jan [cited 2019 Aug 6];2(1):25-39. Available from:

http://doi.wiley.com/10.1002/2017GH000115

8. Agrawal S, Yamamoto S. Effect of Indoor air pollution from biomass and solid fuel combustion on symptoms of preeclampsia/eclampsia in Indian women. Indoor Air [Internet]. 2015 Jun;25(3):341-52. Available from:

http://doi.wiley.com/10.1111/ina.12144

9. Bonjour S, Adair-Rohani H, Wolf J, Bruce NG, Mehta S, Prüss-Ustün A, et al. Solid fuel use for household cooking: country and regional estimates for 1980-2010. Environ Health Perspect [Internet]. 2013 [cited 2019 Aug 6];121(7):784-790. Available from: http://dx.doi.org/10.1289/ehp.1205987

10. Baumgartner J, Schauer JJ, Ezzati M, Lu L, Cheng C, Patz J, et al. Patterns and predictors of personal exposure to indoor air pollution from biomass combustion among women and children in rural China. Indoor Air [Internet]. 2011 Dec;21(6):479_ 88. Available from: http://doi.wiley.com/10.1111/j.1600-0668.2011.00730.x

11. Kodgule R, Salvi S. Exposure to biomass smoke as a cause for airway disease in women and children. Curr Opin Allergy Clin Immunol [Internet]. 2012 Feb;12(1):8290. Available from: https://insights.ovid.com/crossref?an=00130832-20120200000015

12. Fullerton DG, Bruce N, Gordon SB. Indoor air pollution from biomass fuel smoke is a 
medRxiv preprint doi: https://doi.org/10.1101/19010801; this version posted November 2, 2019. The copyright holder for this preprint (which was not certified by peer review) is the author/funder, who has granted medRxiv a license to display the preprint in perpetuity. It is made available under a CC-BY-NC-ND 4.0 International license .

major health concern in the developing world. Trans R Soc Trop Med Hyg [Internet]. 2008 Sep;102(9):843-51. Available from:

http://www.ncbi.nlm.nih.gov/pubmed/18639310

13. Myanmar factsheet - Clean Cooking Alliance [Internet]. Global Alliance for Clean Cookstove. 2018 [cited 2019 May 5]. Available from: https://www.cleancookingalliance.org/binary-data/RESOURCE/file/000/000/508-1.pdf

14. Clean Cooking Alliance- Myanmar [Internet]. United Nations Foundation. 2019 [cited 2019 Apr 4]. Available from: https://www.cleancookingalliance.org/countryprofiles/58-myanmar.html

15. CESD and the International Management Group. Myanmar's Experiences with the Millennium Development Goals and Perspectives on the Post 2015 Agenda [Internet]. 2014. Available from: https://mdricesd.files.wordpress.com/2014/02/publicationexperiences-with-mdgs-2014-en-sm.pdf

16. Ministry of Health and Sports (MoHS) and ICF. Myanmar Demographic Household Survey 2015-16 [Internet]. Nay Pyi Taw, Myanmar, and Rockville, Maryland USA; 2017. Available from: https://dhsprogram.com/pubs/pdf/FR324/FR324.pdf

17. Kingsley Ezeh O, Agho KE, Dibley MJ, Hall JJ, Page AN. The effect of solid fuel use on childhood mortality in Nigeria: evidence from the 2013 cross-sectional household survey. Environ Heal [Internet]. 2014 [cited 2019 Aug 10];12:113. Available from: http://www.ehjournal.net/content/13/1/113

18. Balakrishnan K, Dey S, Gupta T, Dhaliwal RS, Brauer M, Cohen AJ, et al. The impact of air pollution on deaths, disease burden, and life expectancy across the states of India: the Global Burden of Disease Study 2017. Lancet Planet Heal. 2019;3(1):e26- 
medRxiv preprint doi: https://doi.org/10.1101/19010801; this version posted November 2, 2019. The copyright holder for this preprint (which was not certified by peer review) is the author/funder, who has granted medRxiv a license to display the preprint in perpetuity. It is made available under a CC-BY-NC-ND 4.0 International license .

39.

19. Bassani DG, Jha P, Dhingra N, Kumar R. Child mortality from solid-fuel use in India: A nationally-representative case-control study. BMC Public Health. 2010;10(491).

20. Khan MN, B. Nurs CZ, Mofizul Islam M, Islam MR, Rahman MM. Household air pollution from cooking and risk of adverse health and birth outcomes in Bangladesh: a nationwide population-based study. Environ Heal [Internet]. 2017 Dec 13 [cited 2019 Aug 6];16(1):57. Available from:

http://ehjournal.biomedcentral.com/articles/10.1186/s12940-017-0272-y

21. Naz S, Page A, Agho KE. Household Air Pollution and Under-Five Mortality in Bangladesh (2004-2011). Int J Environ Health Res [Internet]. 2015 [cited 2019 Aug 10];12:12847-62. Available from: www.mdpi.com/journal/ijerphArticle

22. Kleimola LB, Patel AB, Borkar JA, Hibberd PL. Consequences of household air pollution on child survival: evidence from demographic and health surveys in 47 countries. Int J Occup Environ Health [Internet]. 2015;21(4):294-302. Available from: http://dx.doi.org/10.1179/2049396715Y.0000000007

23. Rana J, Uddin J, Peltier R, Oulhote Y. Associations between Indoor Air Pollution and Acute Respiratory Infections among Under-Five Children in Afghanistan: Do SES and Sex Matter? Int J Environ Res Public Health [Internet]. 2019;16(2910):1-12. Available from: https://www.mdpi.com/1660-4601/16/16/2910

24. Gordon PSB. Europe PMC Funders Group Respiratory risks from household air pollution in low and middle income countries. Lancet Respir Med [Internet]. 2016;2(10):823-60. Available from: http://pubmedcentralcanada.ca/pmcc/articles/PMC5068561/pdf/emss-70175.pdf 
medRxiv preprint doi: https://doi.org/10.1101/19010801; this version posted November 2, 2019. The copyright holder for this preprint (which

was not certified by peer review) is the author/funder, who has granted medRxiv a license to display the preprint in perpetuity.

It is made available under a CC-BY-NC-ND 4.0 International license.

25. Secrest MH, Schauer JJ, Carter EM, Baumgartner J. Particulate matter chemical component concentrations and sources in settings of household solid fuel use. Indoor Air [Internet]. 2017 Nov [cited 2019 Aug 6];27(6):1052-66. Available from: http://doi.wiley.com/10.1111/ina.12389

26. Bartington SE, Bakolis I, Devakumar D, Kurmi OP, Gulliver J, Chaube G, et al. Patterns of domestic exposure to carbon monoxide and particulate matter in households using biomass fuel in Janakpur, Nepal. Environ Pollut. 2017;220:38-45.

27. Dherani M, Pope D, Mascarenhas M, Smith K, Weber M, Bruce N. Indoor air pollution from unprocessed solid fuel use and pneumonia risk in children aged under five years: a systematic review and meta-analysis. Bull World Health Organ [Internet]. 2008 May;86(5):390-398C. Available from:

http://www.ncbi.nlm.nih.gov/pubmed/18545742

28. Misra P, Srivastava R, Krishnan A, Sreenivaas V, Pandav CS. Indoor Air Pollutionrelated Acute Lower Respiratory Infections and Low Birthweight: A Systematic Review. [cited 2019 Aug 10]; Available from: https://academic.oup.com/tropej/articleabstract/58/6/457/1677194

29. Perera FP. Multiple threats to child health from fossil fuel combustion: Impacts of air pollution and climate change. Environ Health Perspect. 2017;125(2):141-8.

30. Mugo NS, Mya KS, Raynes-Greenow C. Exploring causal pathways for factors associated with neonatal, infant and under-five mortality, analysis of 2015-2016 Myanmar Demographic Health Survey. J Glob Heal Reports. 2019;3:1-17.

31. Pope DP, Mishra V, Thompson L, Siddiqui AR, Rehfuess EA, Weber M, et al. Risk of Low Birth Weight and Stillbirth Associated With Indoor Air Pollution From Solid 
medRxiv preprint doi: https://doi.org/10.1101/19010801; this version posted November 2, 2019. The copyright holder for this preprint (which was not certified by peer review) is the author/funder, who has granted medRxiv a license to display the preprint in perpetuity. It is made available under a CC-BY-NC-ND 4.0 International license .

Fuel Use in Developing Countries. 2010 [cited 2019 Aug 10];32. Available from: http://www.who.int/indoorair/publications/fuelforlife/en/index.html

32. Naz S, Page A, Agho KE. Household air pollution from use of cooking fuel and underfive mortality: The role of breastfeeding status and kitchen location in Pakistan. PLoS One. 2017;12(3).

33. Yu K, Qiu G, Chan KH, Lam KBH, Kurmi OP, Bennett DA, et al. Association of solid fuel use with risk of cardiovascular and all-cause mortality in rural China. JAMA - J Am Med Assoc. 2018;319(13):1351-61.

34. Gouveia N, Junger WL, Romieu I, Cifuentes LA, de Leon AP, Vera J, et al. Effects of air pollution on infant and children respiratory mortality in four large Latin-American cities. Environ Pollut. 2018;232:385-91.

35. Khalequzzaman M, Kamijima M, Sakai K, Chowdhury NA, Hamajima N, Nakajima T. Indoor air pollution and its impact on children under five years old in Bangladesh. Indoor Air. 2007;17(4):297-304.

36. Mishra V, Smith KR, Retherford RD. Effects of cooking smoke and environmental tobacco smoke on acute respiratory infections in young Indian children. Popul Environ. 2005;26(5):375-96.

37. Sonego M, Chiara Pellegrin M, Becker G, Lazzerini M. Risk Factors for Mortality from Acute Lower Respiratory Infections (ALRI) in Children under Five Years of Age in Low and Middle-Income Countries: A Systematic Review and Meta-Analysis of Observational Studies. PLoS One [Internet]. 2015 [cited 2019 Aug 10];10(1). Available from: https://journals.plos.org/plosone/article?id=10.1371/journal.pone.0116380 
medRxiv preprint doi: https://doi.org/10.1101/19010801; this version posted November 2, 2019. The copyright holder for this preprint (which

was not certified by peer review) is the author/funder, who has granted medRxiv a license to display the preprint in perpetuity.

It is made available under a CC-BY-NC-ND 4.0 International license .

38. Gordon SB, Bruce NG, Grigg J, Hibberd PL, Kurmi OP, Lam K bong H, et al.

Respiratory risks from household air pollution in low and middle income countries.

Vol. 2, The Lancet Respiratory Medicine. 2014. p. 823-60.

39. Epstein MB, Bates MN, Arora NK, Balakrishnan K, Jack DW, Smith KR. Household fuels, low birth weight, and neonatal death in India: The separate impacts of biomass, kerosene, and coal. Int J Hyg Environ Health. 2013;216:523-32.

40. Pope DP, Mishra V, Thompson L, Siddiqui AR, Rehfuess EA, Weber M, et al. Risk of Low Birth Weight and Stillbirth Associated With Indoor Air Pollution From Solid Fuel Use in Developing Countries. Epidemiol Rev. 2010 Apr;32(1):70-81.

41. Naz S, Page A, Agho KE. Household air pollution and under-five mortality in Bangladesh (2004-2011). Int J Environ Res Public Health [Internet]. 2015 Oct;12(10):12847-62. Available from: http://www.mdpi.com/1660-4601/12/10/12847 